\title{
68-English language teaching model proposal for Deaf and Hard of Hearing students
}

Sila AY'

\section{Özgür ŞEN BARTAN²}

APA: Ay, S. \& Şen Bartan, Ö. (2022). English language teaching model proposal for Deaf and Hard of Hearing students. RumeliDE Dil ve Edebiyat Araștırmaları Dergisi, (26), 1082-1097. DOI: 10.2900o/rumelide.1076386.

\begin{abstract}
This study tries to explore English language learning conditions of Deaf and Hard of Hearing (DHH) students in Turkey and worldwide. To this end, descriptive research method was carried out to find out the characteristics of DHH English language learners and their ways of communicationand certain foreign language teaching methods and/or techniques recommended for this group of learners. Within the framework of these objectives, the study investigated English language learning conditions of DHH students in Turkey and worldwide through the literature review of both empirical and theoretical studies concerning DHH English learners. Briefly, the results of the research shows that there have been few studies on DHH English language learners in Turkey and DHH learners do not have access to appropriate English language teaching. Having examined the studies concerning DHH English language learners worldwide, there are some practical implications regarding their characteristics, communication ways/needs, and methods and techniques recommended for this group of learners. In brief, within the scope of the data derived from this study, the proposed model of teaching English to DHH learners basically includes components such as visualisation, using technological tools, teaching strategies of reading and vocabulary, constructing a multilingual learning environment by using national sign language, cued speech, lip reading etc., repetition, explicit teaching, and providing enriched feedback.
\end{abstract}

Keywords: Deaf and Hard of Hearing learners of English, English language teaching, English teaching model

\section{Sağır ve işitme kayılı öğrencilerin İngilizce öğretimine yönelik bir model önerisi}

\section{$\ddot{O} \mathbf{z}$}

Bu çalışmada Türkiye'de ve dünyada Sağır ve işitme kayıplı öğrenciler ve İngilizce öğrenme durumları ele alınmaktadır. Bu amaç doğrultusunda araştırmada, betimsel araştırma yöntemi kullanılmıştır. Çalışma İngilizce öğrenen Sağır ve işitme kayıplı öğrencilerin karakteristik özellikleri ve farklı iletişim yollarını ve bu gruba yönelik yabancı dil öğretimi yöntem ve/veya tekniklerini belirlemeyi amaçlamaktadır. Çalışmada belirlenen amaç çerçevesinde alan yazında kuramsal ve uygulamalı çalışmalar incelenerek Türkiye'de ve dünyada Sağır ve işitme kayıplı öğrencilerin İngilizce öğrenme durumları ortaya çıkarılmaya çalışılmıştır. Buna göre, ülkemizde bu gruba yönelik olarak yapılan

Doç. Dr, Ankara Üniversitesi, Dil ve Tarih Coğrfafya Fakültesi, Dilbilimi Bölümü, Genel Dilbilim ABD (Türkiye, Ankara), silay@gmail.com, ORCID ID: 00oo-0002-8773-5522 [Araștırma makalesi, Makale kayıt tarihi: 15.12.2022-kabul tarihi: 20.02.2022; DOI: 10.29000/rumelide.1076386]

Dr. Öğrr. Üyesi, Kırıkkale Üniversitesi, Fen Edebiyat Fakültesi, Batı Dilleri ve Edebiyatları Bölümü, Mütercim-Tercümanlık (İngilizce) ABD (Kırıkkale, Türkiye), ozgursen1@yahoo.com, ORCID ID: 00oo-ooo2-7351-7858

Adres $\mid$ Address

RumeliDE Dil ve Edebiyat Araştırmaları Dergisi Osmanağa Mahallesi, Mürver Çiçeği Sokak, No:14/8 Kadıköy - İSTANBUL / TÜRKIYE 34714 e-posta: editor@rumelide.com

RumeliDE Journal of Language and Literature Studies Osmanağa Mahallesi, Mürver Çiçeği Sokak, No:14/8 Kadıköy - ISTANBUL / TURKEY 34714 tel: +90 $5057958124,+902167730616$

phone: +90 505 7958124, +90 2167730616 
çalışmalar oldukça sınırlıdır ve Sağır ve işitme kayıplı öğrencilerin uygun bir İngilizce öğretimine erişimi yoktur. Dünya genelinde, ilkokuldan yükseköğretime kadar eğitimin farklı kademelerinde öne çlkan uygulamalar incelenerek İngilizce öğrenen Sağır ve işitme kayıplı öğrencilerin özellikleri, kullanılan farklı iletişim yolları ve yöntem ve teknikler üzerine yapılan uygulama önerileri araştırmamızda betimlenmiştir. Toplanan veriler ışığında önerilen model, özetle görselleştirme, teknoloji temelli araçların kullanımı, okuma ve sözcük öğrenimi stratejilerinin öğretimi, işaret dili, ipuçlu konuşma, dudak okuma ve benzeri çok dilli öğrenme ortamı oluşturma, açı İngilizce öğretimi, tekrar ve zenginleştirilmiş geri bildirimi kapsayan bileşenlerden oluşmaktadır.

Anahtar kelimeler: İngilizce öğretimi, sağır ve işitme kayıplı öğrenciler, İngilizce öğretimi modeli

\section{Introduction}

There are approximately 70 million deaf people (The World Federation of the Deaf, 2021) in the world (The World Federation of the Deaf, 2021)and also threre are around 32 million deaf children globally. And many deaf children struggle to learn to read, often due to a lack of resources bridging sign language and reading (European Union of the Deaf/EUD).

In Turkey, approximately 2 million deaf citizens exist, and it is reported that 353,610 students participating in either special education schools/classes or in inclusive education according to the Ministry of National Education. Besides, There are 836,00o (Male: 406,00o- Women: 429.0oo) people over the age of 15 who have difficulty in hearing. The ratio of this number to the general population is estimated as $1.1 \%$ in 2021. According to the Ministry of National Education, the total number of students studying in special education schools, special education classes and inclusive classes in 2018-2019 is 398,815 . It is indicated that 53,814 students in special education schools, 49,304 students in special education classes and 295,697 students in inclusive education continue formal education. In summary, it is seen that students who receive formal education are mostly involved in inclusive education (Statistics Bulletin for the Disabled and Elderly, 2021).

Most of the Deaf and Hard of Hearing (DHH) students in Turkey receive education together with hearing children in schools that provide mainstream education, and some of them receive special education in schools special for DHH learners (Statistics Bulletin for the Disabled and Elderly, 2021). Students who are educated within the scope of the first method are referred to as inclusive students. In this context, the special educational needs of DHH students are closely related to communication. Hearing loss creates difficulties for these students to understand the spoken language used by their teachers and peers, and to be understood by them. In addition, since these students struggle with understanding Turkish language problems arise in both understanding and producing written and oral texts. Similarly, the problem continues and deepens in teaching English as a foreign language. English is not taught in special education schools for DHH students. Also in inclusive (mainstream) education, DHH students can take classes other than English together with their hearing peers, but they are exempted from English education. Regarding the Special Education Services Bylaws (Özel Eğitim Hizmetleri Yönetmeliği), DHH students have the right to take English course, but if they fail their grade point averages are written on their report cards (Special Education Services Bylaws, 2020). As a result, the majority of DHH students do not attend English classes.

It is stated that DHH students not only need special learning methods and needs, but also have a special history and they are socially, culturally and linguistically special. They should also enjoy the positive

\footnotetext{
Adres | Address

RumeliDE Dil ve Edebiyat Araştırmaları Dergisi Osmanağa Mahallesi, Mürver Çiçeği Sokak, No:14/8 Kadıköy - İSTANBUL / TÜRKIYE 34714 tel: +90 $5057958124,+902167730616$

RumeliDE Journal of Language and Literature Studies

Osmanağa Mahallesi, Mürver Çiçeği Sokak, No:14/8

Kadıköy - ISTANBUL / TURKEY 34714

e-mail: editor@rumelide.com,

phone: +90 5057958124 , +90 2167730616
} 
aspects of globalization and the opportunities of technical developments. However, they often cannot participate in foreign language teaching; foreign language approaches, methods and techniques are insufficient; teachers are also not adequately equipped and prepared for this group of learners (Domagała-Zyșk \& Kontra, 2016).

Having introduced DHH students' demographic details and English language learning needs, it is necessary here to clarify exactly what is meant by the terms used in this study such as Deaf, individual with hearing loss, and inclusive student.

Deaf: Individuals who use sign language as their mother tongue and choose to be in a cultural belonging that centres sign language (Kemaloğlu, 2016; Ladd, 2003: 33). While the term deaf with a "lowercase d" is used in the field of health the "uppercase D" Deaf is used to represent a society and culture in other fields Deaf with a capital D indicates an identity for people with hearing loss. Hearing loss: Hearing loss is the result of impaired auditory sensitivity and/or diminished speech intelligibility of the physiological auditory system. Individuals with hearing loss are sometimes described as deaf or hard of hearing based on the type, degree, and configuration of hearing impairment. (https://www.asha.org/practiceportal/clinical-topics/hearing-loss/)Hearing loss is graded as follows: 0-25 Normal Hearing (no hearing loss); 26-40 dB Very Mild Hearing Loss; 41-55 dB Mild Hearing Loss; 56-70 dB Moderate Hearing Loss; 71-9o dB Severe Hearing Loss; $91 \mathrm{~dB}$ and above Very Severe Hearing Loss (World Health Organization, 2007). In terms of education, Johnson \& Seaton (2012) depicts the impact of hearing loss:

The degree of hearing loss can have significant implications for children with hearing loss, as even a slight hearing loss can be educationally significant for children in the school setting. Educationally significant hearing loss has been defined as "any hearing loss that potentially interferes with access to classroom instruction and impacts a child or youth's ability to communicate, learn and develop peer relationships (Johnson \& Seaton, 2012, p. 43).

Individual with hearing loss: Individuals who have bilateral congenital peri/pre-lingual moderate/advanced and more advanced hearing loss (Kemaloğlu, 2014) and whose participation in common social life and social activities is restricted (Kemaloğlu, 2016).

Inclusive student: In this study, DHH children who were diagnosed with hearing loss by audiological tests, and were determined as individuals with "hearing loss" by the Guidance Research Center, and who were educated in the same classes as their peers in mainstream education were defined as inclusive students.

DHH students in inclusive education receive Turkish language support in education support room service (Akay, 2015). The support given separately from the classroom in the education support rooms is sometimes criticized owing to the fact that students miss the lessons in their main classroom. In the literature, there is no information about whether these students receive English support in the support rooms.

Also, DHH students in Turkey can also be exempt from foreign language courses at the university stage. (YÖK,2021). In the context of higher education in Turkey, Anadolu University - Integrated School for the Disabled offers undergraduate and associate degree programs for DHH students (YÖK, 2021). More higher education opportunities will increase the access opportunities to education for students with disabilities, as well as encourage them to learn English. For this reason, it has become more important for DHH students to access English teaching in primary and secondary education, which form the basis of higher education.

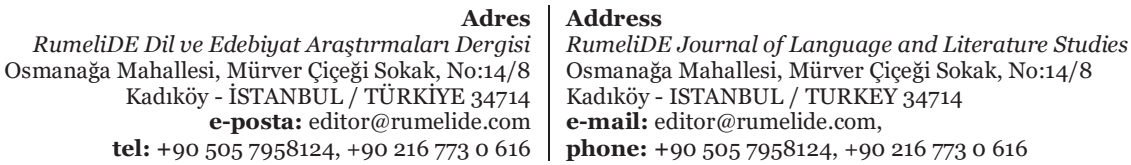


In this study, Deaf and Hard of Hearing students and their English learning situations in Turkey and worldwide are discussed. The research questions of the study are as follows:

1. What are the characteristics of DHH English language learners and their ways of communication?

2. What are certain foreign language teaching methods and/or techniques recommended for this group of learners?

\section{Method}

In this study, descriptive research method, which is widely used in qualitative research, was carried out. The aim of the research is to describe the conditions of Deaf and Hard of Hearing students learning English in Turkey and worldwide. Descriptive analysis is generally used in "processing data that does not require detailed separation on the qualitative data set" (Baltac1, 2019). After reviewing the studies in the field within the framework of the characteristics and different ways of communication of DHH students learning English and foreign language teaching methods and/or techniques for this group, the data were summarized with a descriptive analysis and the studies conducted in Turkey and worldwide were interpreted. In conclusion, a foreign language teaching model for this group was suggested regarding the findings of this study. Additionally, this study adopts Sociocultural Theory of Cognitive Development and Vygotsky's Zone of Proximal Development and Scaffolding (Vygotsky, 1978) as an instructional design model for the proposed model of teaching and learning of English language learners of DHH. This design model is highly accepted for the DHH and learners who need special education (Eg. Herman, Hulme, Roy, and Kyle, 2020).

The models help researchers and teachers to plan the overall process intentionally. To this end, Branch \& Kopcha mention that "instructional design is intended to be an iterative process of planning outcomes, selecting effective strategies for teaching and learning, choosing relevant technologies, identifying educational media and measuring performance" (p. 77).

\section{Findings}

The findings of the study are presented by examining the studies in Turkey and worldwide regarding the research questions:

1. What are the characteristics and different ways of communication of Deaf and Hard of Hearing students learning English?

2. What are the foreign language teaching methods and/or techniques for this group?

Firstly, this paper seeks to address the following question: What are the characteristics of DHH English language learners and their ways of communication?

In a study investigating the foreign language learning characteristics of Deaf and Hard of Hearing students (Csizér \& Kontra, 2020), the learning processes of 54 students from three European countries were examined. With the use of semi-structured interviews and questionnaires on individual differences to the participants who were deaf, severely deaf and cochlear implanted, their motivation levels, learning methods, and foreign language learning strategies were investigated. The results of the project revealed that DHH students faced difficulties in learning, even though their motivation was high; the use of national sign language is effective in foreign language learning; it is noted that foreign language learning strategies together with autonomous learning methods are effective if they are implemented together

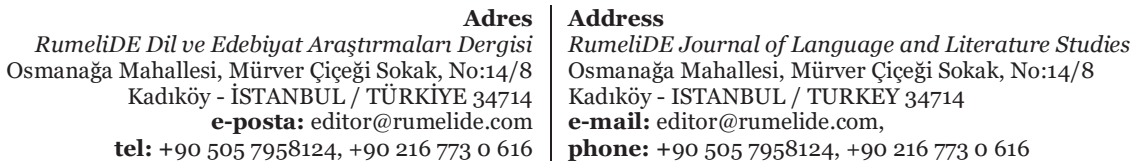


with English teaching. Falkowska (2016) also proposes the use of national sign language as a communication tool in teaching English as a foreign language. As a result of the one-year English teaching practice with 25 Deaf students, the researcher states that an individualized communication method should be chosen according to the needs of the students. In other words, the learning environment can be monolingual, bilingual or trilingual, depending on the student's needs. It is stated that such a language environment improves student performance.

Students' attitudes and motivation towards English lessons is another important issue. Géblová (2011) stated that it is very stressful for Deaf children to learn English, which is applied from the 3rd grade of primary school in Czechia (as cited in Morávková, 2011). Vladovičová states that Deaf students studying at secondary school in Czechia understand the importance of foreign language teaching, but they do not prefer to take the final exams. The researcher cited possible reasons for this low motivation as follows: poor teacher qualifications and inexperience with the Deaf; lack of adaptations for the Deaf and foreign language teaching methods designed for the Deaf (as cited in Morávková, 2011).

It is observed that interesting learning environments increases students' motivation. Kimmel (2001) observed that interactive online journal writing increased the interest of Deaf students by reducing their writing and grammar anxiety. Morávková, (2011) examined the problems of DHH students' motivation to learn English as a foreign language and stated that two-thirds of the participants wanted to learn English even if it was not compulsory; 90\% of the participants use English outside of the classroom; since it is a heterogeneous group, not every student has to learn all four language skills; lip reading skills affects speaking and listening skills. The researcher observed that foreign language students with moderate hearing loss (moderate 56-70 dB) were successful in all four language skills. According to this research, those with moderate hearing loss generally excel in listening and speaking skills. Whereas, those with severe hearing loss (71-90 dB) show little improvement in these skills. If these two groups are together in the classroom, it is recommended to continue teaching with a separate program.

It is stated that DHH students learn all kinds of new information better visually (Mole, McColl, \& Vale, 2006). Regarding visualization, Marschark (2003) states that these students look around more to compensate for sound-related stimuli than those who hear, and they also focus on lip-reading and cues, and they use speech-based coding and visuospatial coding strategies. The results of Gulati's (2016) English teaching lessons with 15 DHH students emphasize that this information is also valid in the foreign language teaching environment. The researcher gives examples of how to visualize the teaching of all skills.

Teaching/learning different language skills depends on DHH students' features and needs. DHH students are a heterogeneous group. This group's features such as chronological age, time of hearing loss, degree of hearing loss, age of first device wearing, first response, family support, resources, awareness, use of technology and pre-school education affect their language skills in both learning Turkish (Efe, 2016) and English (Maschark, 2007; Mayberry, 2002). For example, it is stated that DHH students who attend inclusive education need various activities suitable for their individual needs in addition to their language skills (Szymanski, Lutz, Shahan, \& Gala, 2013).

It is emphasized that the individual characteristics of this heterogeneous group have a striking effect on learner needs. Piniel, Kontra, and Csizér (2016) state that although they are willing and creative towards this group, English teachers in Hungarian schools have serious communication problems owing to the fact that they do not know their national sign language. Researchers suggest that, for a more effective

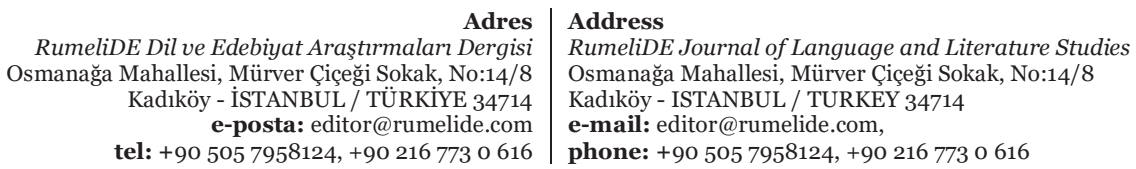


English language teaching, English teachers should be instructed about special education, should benefit from the experience of special education teachers, and learn Hungarian Sign Language (HSL).

Furthermore, Csizér, Kontra, and Piniel (2015) concluded in their study with DHH students that their motivation to learn English and their second language self-perceptions were moderate. According to this study, DHH students do not continue their English language learning with high energy.

Moreover, Pritcchard (2016) used BSL (British Sign Language) and ASL (American Sign Language) teaching as a means of communication in English classes of DHH Polish students. In other words, teaching BSL and ASL instead of or together with spoken English is also recommended as another way of teaching a foreign language and a form of communication. In this case, by taking into account his own needs and skills, students can choose whether they want to learn English, BSL or ASL.

However, thanks to early diagnosis and intervention, cochlear implant placement at a very early age, the support of family and state-supported private rehabilitation centers and similar developments in recent years, it is observed that deaf children in Turkey are more advanced than their parents in terms of language skills. However, although DHH students can speak, they may prefer to communicate mainly through sign language. For this reason, it is recommended that, at least at the entry level, teachers working with DHH students should know sign language, finger alphabet, or deaf culture and their communication styles (Pritchard, 2016).

These factors which depict DHH learners' ways of communication also affect foreign language learning conditions of DHH students. And with these differences, it is clear that foreign language learners have quite different skills and have different needs. In many countries around the world, English is taught as a foreign language for this group. Although some countries exempt students who learn English from speaking and listening skills, in other countries, these skills are also placed in the program according to their individual differences. It is claimed that the student who can speak in their national spoken language can also speak and understand English.

In brief, Figure 1 shows the characteristics of DHH English language learners and their ways of communication.

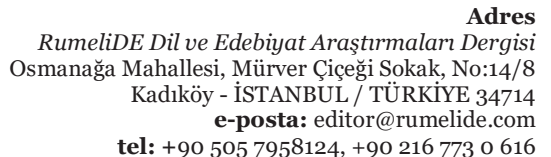

dres 8

RumeliDE Journal of Language and Literature Studies Osmanağa Mahallesi, Mürver Çiçeği Sokak, No:14/8 Kadıköy - ISTANBUL / TURKEY 34714 e-mail: editor@rumelide.com, phone: +90 $5057958124,+902167730616$ 


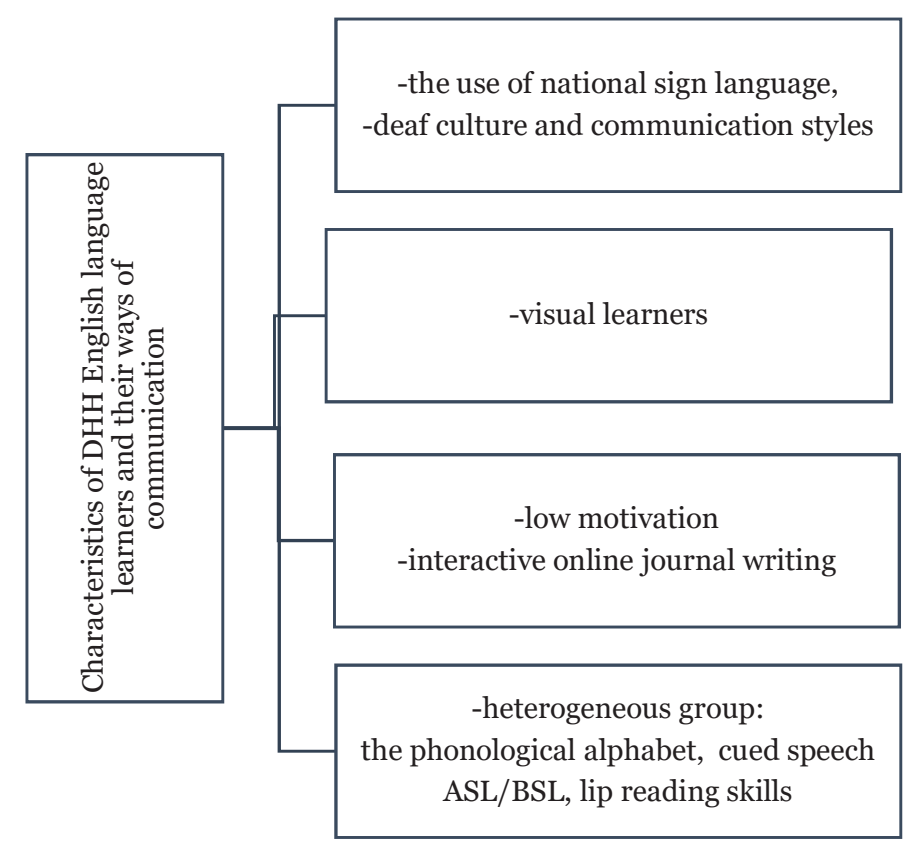

Figure 1. The characteristics of DHH English language learners and their ways of communication

The second question of the research addressed is: What are the foreign language teaching methods and/or techniques for this group?

In particular, regarding teaching English to DHH students generally reading, vocabulary teaching, listening and speaking skills were studied as foreign language teaching skills.

Far too little attention has been paid to teaching English to DHH students in Turkey. There have been two studies found on this subject. The first is the study conducted by Birinci (2014) in which she investigated the effectiveness of using various visual tools in teaching vocabulary to DHH students within the scope of English course. In this study, a total of 50 words, 10 words per week, were taught to 80 DHH students from a special education vocational high school in Ankara. While these words were taught to the experimental group, visual tools were used besides sign language. According to the results of the research, it has been observed that the use of visual tools in foreign language vocabulary learning of DHH students is more effective than just using sign language as a medium by not using any visual tools. The second one is the study of Arslanoğlu (2015), in which the researcher studied the effect of computer assisted language education on the motivation of DHH Turkish students and their English vocabulary development. In this study, it is revealed that computer-assisted language education has a positive effect on students' English vocabulary development and motivation. During the implementation, a website called "Quizlet" was used. The researcher prepared vocabulary learning activities according to the topics covered on this site and added and used digital pictures for each of these words. Finally, a comprehensive report on English language learning of disabled university students was published (Turan, Özel \& Dayı, 2016). The recommendations in the conclusion section of the report, limited to the DHH students are as follows:

a) Regarding foreign language learning of disabled people; there is a need for both

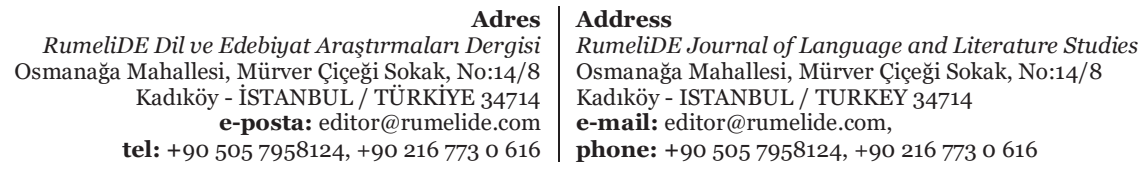


developing new methods and increasing accessible resources.

b) During pre-service teachers' education, practices that increase awareness about disability and educational/instructive efficiency should be developed.

c) Teachers who do not feel psychologically ready can be supported in different ways.

d) If teacher candidates have the chance to experience teaching DHH learners before they graduate from the department, they can develop a more sensitive but less emotional perception before starting the profession.

e) It is important for disabled individuals to play an active role in such processes (Turan, Özel \& Dayı, 2016).

Globally, there is a considerable amount of literature on teaching methods and techniques for foreign language to DHH learners.

Sedláčková (2016), for instance, states that primarily reading studies and native language development (Spencer \& Marschark, 2010) of DHH learners are carried out with early age participants, and points out that this field should be examined and its data should be used for ELT. For this reason, in this study, some of the studies on reading studies and native language development of DHH learners and English teaching related to reading skills were also examined. Sedláčková (2016) examined the effect of teaching reading strategies for DHH university students learning English and suggested explicit teaching, repetition and reading strategies.

Regarding Turkish reading skill, DHH inclusive students in Turkey were evaluated, and it was observed that those who read the text at the instructional level can tell most of the characters and, they can talk about the main idea of the text, however, they have difficulties in expressing some details. It is seen that they can use some question-answer strategies in their answers to the questions about the text, but they have difficulty in answering the questions of knowledge and experience (Genç, Girgin, \& Karasu, 2020). In addition, Karasu (2011) reports that students with cochlear implants can acquire skills such as explaining what they read, answering comprehension questions and filling in the blanks like their hearing peers, but they are behind their hearing peers.

Another major recommendation for DHH students is phonics awareness, Pritcchard (2016), for instance, emphasizes that Phonics Instruction is very useful in teaching English for DHH students. Many studies (Hatcher, Hulme, \& Snowling, 2004; Herman, Kyle, Roy, 2019) mention the benefits of this training. It is stated that DHH students have limited ability to hear their own voices, these features prevent learning the correct pronunciation and intonation of words, they cannot produce the correct sounds without teacher support or speech therapy, and it is more difficult for them to learn pronunciation than their hearing peers (Domagała-Zysk, 2013). However, it is important to note that Domagała-Zysk (2013) points out that DHH students would want to speak a foreign language with the help of technology if they can speak their mother tongue (verbal language). For the researcher, meeting this demand is only possible by being exposed to foreign language input and providing access to opportunities.

It has been widely suggested that pronunciation and English speaking education in general begins with phonology education. Phonological awareness means being aware of the phonemes that make up a word (Goswami \& Bryant, 1990). Phonological education is a training carried out before and during the initial literacy phase to create phonological awareness. English is an alphabetic language and has a complex phonological system. Unlike Turkish, which has an almost transparent orthography, it has an opaque alphabet which means a letter has multiple pronunciations (Yang, 2020).

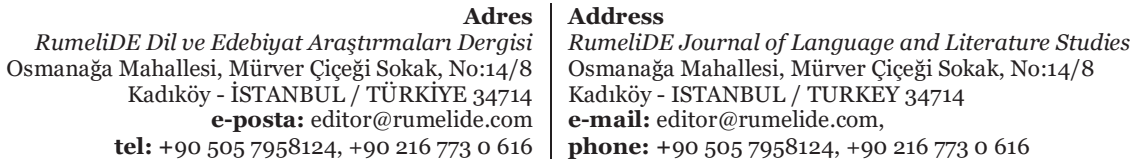


1090 / RumeliDE Journal of Language and Literature Studies 2022.26 (February)

English language teaching model proposal for Deaf and Hard of Hearing students / S. Ay \& Ö. Şen Bartan (pp. 1082-1097)

There are different sub-techniques of phonemic awareness:

Phonemic identity: Recognizing frequently used sounds in different words: distinguishing the /p/ sound in words such as "pat", "pick", "play",

Phonemic isolation: Distinguishing each phoneme in a word: like knowing that the word "cat" starts with /c/ and ends with the sound / $\mathrm{t} /$

Phonemic substitution: Converting one word to another by changing a phoneme: Changing the / $t$ / sound to "cap" the word "cat"

Segmenting the word (word segmenting): Separating the word into the sounds it contains, for example, breaking the word "lap" into the sounds it contains: /l/, /a/, /p/

Verbal Blending: Finding out which word is formed by the sounds given one by one: Being able to say the word "red" when the sounds /r/, /e/, /d/ are given,

These studies can be done on the basis of words, as well as focusing on the word in a sentence:

Touch your N-O-S-E; Kick your F-EE-T; J-U-M-P up and down; H-O-P all around; Clap your H-A-N-D$\mathrm{S}$; Wave your A-R-M-S

As the level of student improves, the difficulty of the exercises is being increased: KI-CK your F-EE-T; Like T-OU-CH your NOSE (Yang, 2020).

Phonological awareness training is often recommended for students with reading difficulties. Phonological awareness, among other language skills, is seen as a predictor of accurate and fluent reading for DHH students (Herman, Hulme, Roy, \& Kyle, 2020). The effectiveness of the synthetic phonetics instruction approach in the context of teaching English reading to DHH students has been noted in a large project (Herman et al., 2020).

In their project entitled Integrated Phonics \& the Teaching of Reading to DHH, Herman, Hulme, Roy, and Kyle (2020) adapted a digital book (Floppy's Phonics) that teaches general phonics to DHH students. In the program called Visual Phonics by Hand (2020), phonics education is given with different language skills. It is emphasized that deaf children are less exposed to spoken language; therefore, an explicit phonology education is very beneficial this group and has a positive effect on reading comprehension.

Similarly, students with improved phonological awareness can read sentences composed of letters they learned in the primary reading-writing process more accurately and fluently (Erdoğan, 2012; Anthony \& Francis, 2005). Güldenoğlu, Kargın, and Miller (2012) conducted a comparative study on the decoding and reading comprehension performances of good and poor readers. A positive significant relationship was found. In addition, Turna and Güldenoğlu (2019) examined the relationship between phonological decoding skills and word reading fluency and concluded that there were significant positive relationships between phonological decoding skills and word reading fluency sub-skills. Girgin (1987) found that there is a correct ratio between vocalizing and finding the right option in DHH students.

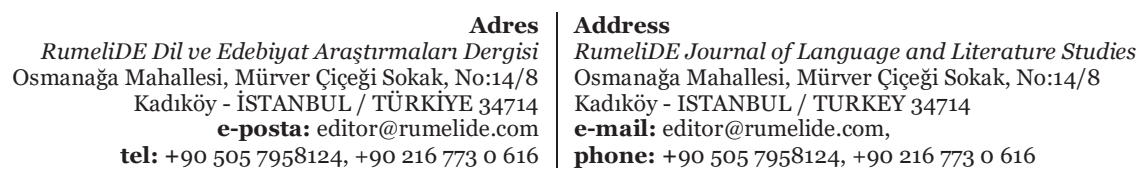


The subject has also been studied in the field of English teaching (Ünal Gezer \& Dixon, 2017) and it has been determined that the pronunciation knowledge of 6,7 and 8th grade learners of English affects their writing performance.

Moritz (2016) stated that determining the types of the errors in speaking English as a foreign language of DHH students will help to understand the types of this group. DHH students in the study group make mistakes in consonant sounds rather than vowel sounds, and this has been noted as one of the important factors affecting speech comprehension. Moreover, Podlewska (2016) argued that cued speech teaching had a positive effect on speaking skills in the four-year English teaching practice for DHH students. These findings propose that DHH students who can speak their national spoken language can also speak English.

Another study with DHH foreign language students is Vanderplank's $(2016,2019)$ research on improving listening skills. Vanderplank's $(2016,2019)$ studies investigated the effect of foreign language teaching method with the caption tool in the target language on videos (films) in the target language. For example, it is stated that the applications made by putting English captions in English films cause improvement in terms of phonology, vocabulary and listening skills (see Mitterer and McQueen, 2009). In his study, Vanderplank (2016) guided British DHH foreign language students to use DVD and target language caption tool in many foreign languages (French, German, Italian and Spanish) for a long time. The results of the study show that the tool is effective in foreign language teaching for DHH students and this tool should be used more consciously, for example, producing foreign language activities with captions.

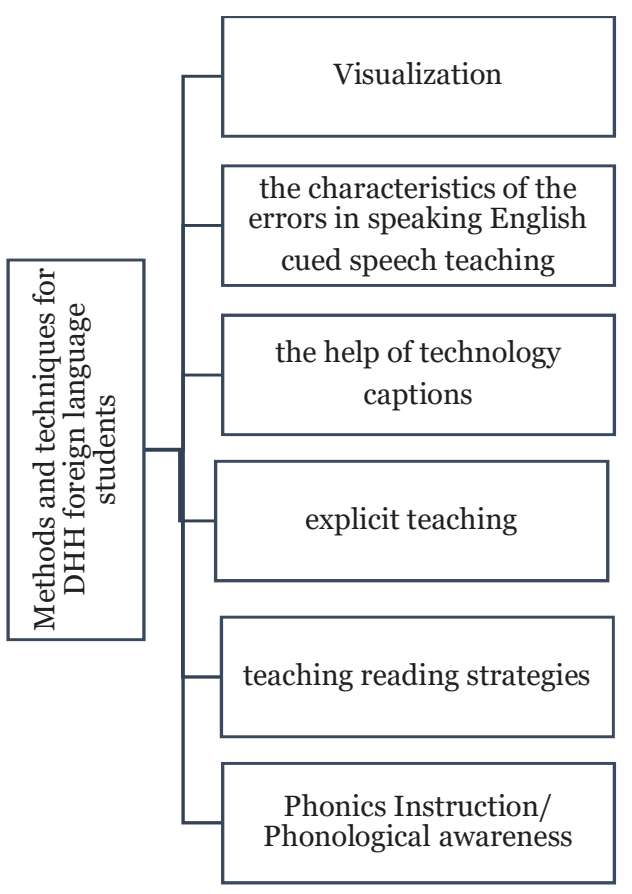

Figure 2. Methods and techniques for DHH foreign language students

\section{Conclusion and recommendations}

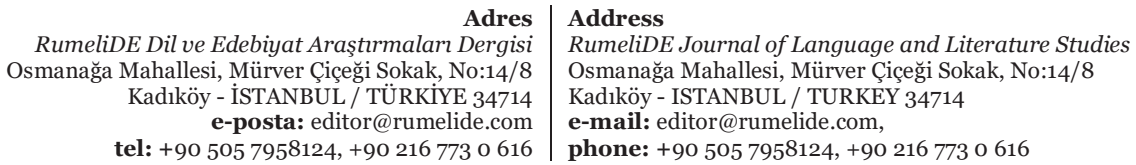

RumeliDE Journal of Language and Literature Studies

Osmanağa Mahallesi, Mürver Çiçeği Sokak, No:14/8

Kadıköy - ISTANBUL / TURKEY 34714

e-mail: editor@rumelide.com,

phone: +90 5057958124 , +90 2167730616 
In this study, DHH students and their English learning situations in Turkey and worldwide are discussed. The characteristics and different communication ways of English language learners of DHH and the methods and/or techniques for this group were examined. And as a result, a teaching model for DHH foreign language students is suggested.

The results of the study and recommendations made in this direction are presented below:

1. The results of the study show that the foreign language learning situations and needs of DHH students are quite heterogeneous.

2. Communication channels are diverse. Multilingual learning environments can be summarized as follows:
a) National (e.g. Turkish Sign Language) sign language translations
b) Finger alphabet
c) Lip speech and reading
d) Effective use of cued speech method
e) BSL/ASL teaching
f) Adding captions to audio-visual tools
g) International Phonetic Alphabet

Learning environments should be prepared for this diversity and the needs of the group should be borne in mind.

3. Studies on teaching English are limited both in Turkey and worldwide, and they are at the initial stage in terms of methodology. There is not yet a program in Turkey that will meet the special education needs of this group.

4. There are features that immensely affect their English learning such as calendar age of DHH students, time of hearing loss, degree of hearing loss, age of first device wearing, age of cochlear implantation, first response, family support, resources, awareness, use of technology and preschool education, whether or not they can speak the national language. Therefore, various teaching models should be presented according to the individual differences of this heterogeneous group. English teaching options should be created.

5. It is suggested that DHH students who cannot speak their national language(s) (for example Turkish) need more sign language support, use captions and/or are prone to learn the Sign Language of the target language such as BSL or ASL. For this sub-group of learners a teaching and learning approach based on reading and writing skills is recommended.

6. Also it is claimed that DHH students who can speak in their national spoken language(s) can often also speak English. Although differences occur within this group, it is seen that English reading, writing, listening and speaking skills can develop when they are supported correctly.

7. Some of the conclusions and suggestions of the researchers and practitioners for DHH students are as follows:

a) They have low motivation to learn English (Géblová, 2011; Morávková, 2011).

b) They learn better through visualization (Mole, McColl, \& Vale, 2006; Gulati, 2016).

c) Teaching the phonological alphabet, cued speech (Podlewska, 2016) and the use of national sign language (Falkowska, 2016; Csizér \& Kontra, 2020) are beneficial.

d) Some students can be taught BSL (British Sign Language) and/or ASL (American Sign Language) in English classes instead of English verbal skills, and it is beneficial to have English teachers who know finger alphabet, deaf culture and communication styles (Pritcchard, 2016).

e) It is useful to teach English language explicitly, a lot of repetition and reading strategies (Sedláčková, 2016) are also recommended.

f) It is reported that using videos with captions in the target language has a positive effect on listening skills and foreign language learning (Vanderplank, 2016, 2019).

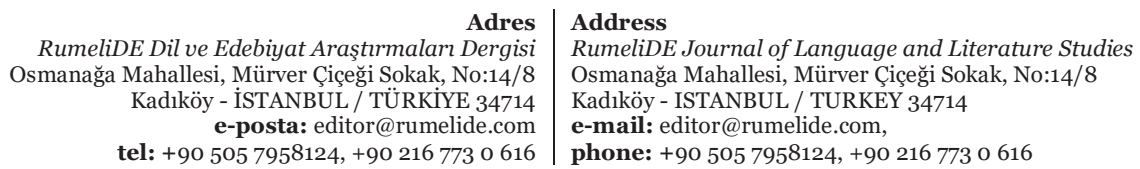


8. In addition, studies on both national spoken language teaching (for example, Turkish) and teaching English as a foreign language indicate that there is a positive relationship between phonetic instruction and reading.

It is clear from the suggestions that the field of DHH learners and teachers need a foreign language teaching model specific for them. What are the possible components of an English language teaching model for DHH students? It is necessary to conclude a model based on the mentioned seminal researches.

Having reviewed the key points utilizing the related studies, it should be noted that these points are highlighted due to the needs of $\mathrm{DHH}$ learners; however, other fundamental principles of foreign language teaching and general learning and/or teaching principles should be borne in mind as well while teaching DHH. Also, the researchers expand these points and add another dimension which is giving feedback for motivation. Jensen (2005) recommends giving feedback to change student states positively, which refers to motivation. He suggests feedback as follows:

Give feedback. It's one of the greatest sources of intrinsic motivation. Set up learning that students can do with built-in, self-managed feedback. A computer does this perfectly, but so do well designed projects, group work, checklists, dramatic presentations, peer editing, and rubrics (Jensen, 2005).

Depending on the theoretical and specifically applied researches on foreign language learning and teaching, this study suggests a teaching/learning model for both teachers of DHH learners and DHH learners themselves. The model is entitled Visual EMPIRE. As the mnemonic suggests, briefly seven dimensions need to be considered. To ensure that foreign language teachers can use this model to design learning activities and/or materials or adopt ready-made foreign language materials for DHH learners, the researchers present an analytical framework of the model as shown in Table 1.

Table 1. The analytical framework of Visual EMPIRE

\begin{tabular}{|l|l|}
\hline Visual EMPIRE Dimensions & Ask Questions about each dimension. \\
\hline Visualization & $\begin{array}{l}\text { How can I visualize my teaching materials? How can I } \\
\text { visualize the ready-made materials/activities? }\end{array}$ \\
\hline Electronic-reading & $\begin{array}{l}\text { How can I use technology to create motivation and/or } \\
\text { improve cognition? What are some of the reading and } \\
\text { vocabulary strategies that my learners (DHH learners) } \\
\text { can use? }\end{array}$ \\
\hline Multi-lingual and positive learning environment & $\begin{array}{l}\text { Who are my learners? What are their characteristics? } \\
\text { How can I communicate with them? Which ways of } \\
\text { communication (sign language, speaking national } \\
\text { spoken language, lip reading etc.) do my learners } \\
\text { demand/need/prefer? How can I create a positive } \\
\text { environment? }\end{array}$ \\
\hline Phonics Instruction & $\begin{array}{l}\text { How can I utilize phonics awareness before and during } \\
\text { teaching a foreign language? What are the categories } \\
\text { of phonics instruction and how can I design materials } \\
\text { to teach phonics? }\end{array}$ \\
\hline Instructed Language Learning & $\begin{array}{l}\text { How can I design materials that serve for both explicit } \\
\text { and implicit teaching approaches? }\end{array}$ \\
\hline Repetition & $\begin{array}{l}\text { How much DHH learners need repetition? What are } \\
\text { the ways of meaningful memory strategies? }\end{array}$ \\
\hline
\end{tabular}

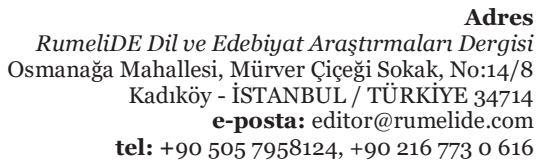

Adres RumeliDE Dil ve Edebiyat Araşttrmaları Dergisi Kadıköy - İSTANBUL / TÜRKIYE 34714 tel: $+905057958124,+902167730616$
Address

RumeliDE Journal of Language and Literature Studies

Osmanağa Mahallesi, Mürver Çiçeği Sokak, No:14/8

Kadıköy - ISTANBUL / TURKEY 34714

e-mail: editor@rumelide.com

phone: +90 505 7958124, +902167730616 
1094 / RumeliDE Journal of Language and Literature Studies 2022.26 (February)

English language teaching model proposal for Deaf and Hard of Hearing students / S. Ay \& Ö. Şen Bartan (pp. 1082-1097)

Enriched Feedback

Why I need to give constant feedback to my learners?

How can I/my learners give varying and positive feedback?

This analytical framework of Visual EMPIRE consists of seven dimensions derived from related studies, and encompasses questions which can possibly encourage teachers/learners to find practical solutions. There may not be standardised or one-size-fits-all answers for all DHH learners, however teachers can find ways and create suitable answers to those questions regarding their learners' special and individual needs. Lastly, further investigation and experimentation into the effect of Visual EMPIRE is strongly recommended to find practical suggestions and to test effectiveness of the model.

\section{References}

Akay, E. (2015). Kaynaştırma ortamındaki işitme engelli öğrencilere destek eğitim odasında uygulanan Türkçe etkinliklerinin incelenmesi. Journal of Education and Special Education Technology, 1 (1), 1-14.

American Speech- Language-Hearing Association (ASHA). (2010). Type, degree, and configuration of hearing loss. Retrieved (22.03.2021) http://www.asha.org/.

American Speech-Language-Hearing Association (2021). Hearing Loss: Ages 5+ (Practice Portal). Retrieved November, 18, 2021, from / Practice-Portal/Clinical-Topics/Hearing-Loss/

Anthony, J. L. \& Francis, D. J. (2005). Development of phonological awareness. Current Directions in Psychological Science, 14 (5), 255-259.

Arslanoğlu, A. (2015). The impact of computer-assisted language learning on the learning impaired Turkish students' motivation and their vocabulary development in English. Council of Higher Education.

Baltacı, A. (2019). Nitel araştırma süreci: Nitel bir araştırma nasıl yapılır?. Ahi Evran Üniversitesi Sosyal Bilimler Enstitüsü Dergisi, 5(2), 368-388.

Birinci, F. G. (2014). The Effectiveness of Visual Materials in Teaching Vocabulary to Deaf Students of EFL (Bachelor's thesis). Retrieved May 9th fromwww.openaccess.hacettepe.edu.tr/handle.

Branch, R. M., \& Kopcha, T. J. (2014). Instructional design models. In Handbook of research on educational communications and technology (pp. 77-87). Springer New York.

Csizér, K. \& Kontra, E. H. (2020). Foreign language learning characteristics of Deaf and Severely Hardof-Hearing student. The Modern Language Journal, 104, 1, (2020) DOI: 10.1111/modl.12630

Csizér, K., Kontra, E. H., \& Piniel, K. (2015). An investigation of the self-related concepts and foreign language motivation of young Deaf and Hard of Hearing learners in Hungary. Studies in Second Language Learning and Teaching 5(2), 229-249.doi: 10.14746/ssllt.2015.5.2.3.

Domagała-Zysk, E. (2013). Using Technology to Teach English as a Foreign Language to the Deaf and Hard of Hearing, In Inclusive Language Education and Digital Technology Beltran, Elina Vilar, Ed.; Abbott, Chris, Ed.; Jones, Jane, Ed., Multilingual Matters, 84-102.

Domagała-Zysk, E. (2015). Learning and teaching strategies in English as a foreign language cClasses for the Deaf and Hard-Of- Hearing students. John Paul II Catholic University of Lublin, Institute of Pedagogy, Centre of Education of the Deaf and Hard-of-hearing.

Efe, A. (2016). Kaynaştırma eğitimine devam eden işitme engelli öğrencilerin yazdıkları öykülerin incelenmesi, Yüksek Lisans Tezi, Özel Eğitim Ảna Bilim Dalı İşitme Engelliler Öğretmenliği Programı, Eskişehir.

Engelli ve Yaşlı İstatistik Bülteni, (2020, April 12). https://www.aile.gov.tr/media/42250/istatistikbulteni-2020-mart.pdf

Erdoğan, Ö. (2012). İlköğretim Birinci Sınıf Öğrencilerinin Fonolojik Farkındalık Becerileri ile Okuma Becerileri Arasındaki İlişki, Eğitim ve Bilim, 37 (166).

Adres Address

RumeliDE Dil ve Edebiyat Araşttrmaları Dergisi Osmanağa Mahallesi, Mürver Çiçeği Sokak, No:14/8 Kadıköy - İSTANBUL / TÜRKIYE 34714 e-posta: editor@rumelide.com tel: +90 $5057958124,+902167730616$

RumeliDE Journal of Language and Literature Studies

Osmanağa Mahallesi, Mürver Çiçeği Sokak, No:14/8

Kadıköy - ISTANBUL / TURKEY 34714

e-mail: editor@rumelide.com,

phone: +90 $5057958124,+902167730616$ 
Falkowska, J. (2016).Monolingual, bilingual, trilingual? Using different languages in an EFL class for the D/deaf. In E. Domagala-Zysk\& E. H. Kontra (Eds.), English as a foreign language for Deaf and Hard of Hearing persons: Challenges and strategies (pp. 55-72). Cambridge, UK: Cambridge Scholars Publishing.

Genç, T., Girgin, Ü. \& Karasu, H. P. (2020). İşitme engelli kaynaştırma öğrencilerinın okuma becerilerinin formel olmayan okuma envanteri ile değerlendirilmesi. Bolu Abant İzzet Baysal Üniversitesi Eğitim Fakültesi Dergisi, 20 (1), 507-526.

Girgin, Ü. (1987). Doğal-işitsel sözel yöntemle eğitim gören işitme engelli çocuklarda okuma-anlama davranışlarının irdelenmesi (Yüksek Lisans Tezi). Yüksek Öğretim Kurulu Ulusal Tez Merkezi’nden edinilmiştir. (Tez No.2279).

Girgin,Ü.; Yaman,F.; Dönmez, P.; Avcı,E.; Akay,E.; Girgin,M.C.; Yurdakul, I.K.; Odabaşı,H.F.; Şahin, Y. L.; Dönmez, O. (2012-2016). İșitme engelli bireylerin okuma yazma eğitimine yönelik mobil bir uygulamanın geliştirilmesi ve değerlendirilmesi Tübitak 1001.

Goswami, U., ve Bryant, P. (1990). Phonological Skills and Learning to Read. Hillsdale, NJ: Erlbaum.

Gulati, B. (2016). Visualizing-The most effective way to teach EFL to deaf and hard of hearing students. In E. Domagała-Zysk\& E. H. Kontra (Eds.), English as a foreign language for Deaf and Hard of Hearing persons: Challenges and strategies (pp. 153-167). Newcastle upon Tyne: Cambridge Scholars.

Hatcher, P.J., Hulme, C. \& Snowling, M.J. (2004) Explicit phoneme training combined with phonic reading instruction helps young children at risk of reading failure. Journal of Child Psychology and Psychiatry, 45(2), 338-358. doi:10.1111/j.1469-7610.2004.00225.x

Herman, R., Hulme, C., Roy, P. and Kyle, F. E. (2020). A pilot study to evaluate an integrated phonics and language programme for the teaching of reading to Deaf and Hearing children. London, UK: Nuffield Foundation.

Herman, R., Kyle, F. Roy, P. (2019) Literacy and phonological skills in hearing dyslexic and deaf children. DOI: $10.1002 /$ rrq.244

Güldenoğlu, B., Kargın, T. ve Miller, P. (2012). İyi ve zayıf okuyucuların kelime işlemleme ve okuduğunu anlama becerilerinin karşılaştırılmalı olarak incelenmesi. Kuram ve Uygulamada Eğitim Bilimleri (KUYEB), 12(4), 2807-2828.

Johnson, C. \& Seaton, J. (2012). Educational Audiology Handbook, 2nd Edition. Boston, MA: Cengage Learning.

Karasu, P. (2011). İşitme engelli öğrenciler ve normal işiten öğrencilerin okuma becerilerinin formel olmayan okuma envanteri ile değerlendirilmesi (Doktora Tezi). Yüksek Öğretim Kurulu Ulusal Tez Merkezi'nden edinilmiştir. (Tez No.296604).

Kemaloğlu, Y.K. (2012). Türkiye de İșitme Kayıplarının ve İşitme Engelinin Genel Görünümü. Turkiye Klinikleri J E.N.T. - Special Topics, 5(2), 1 -10.

Kemaloğlu, Y.K. (2014). Engellilik, kulak burun boğaz (kbb) hekimliği ve İşaret dili. Bozok Tıp Dergisi, 1 (1): $38-53$.

Kemaloğlu, Y.K. (2016). Türkiye'de Sağırların Görünürlüğü ve Toplumsal ve Eğitimsel Sorunları Üzerine Demografik Bir İnceleme. E. Arık (Haz.), Ellerle Konuşmak: Türk İşaret Dili Araştırmaları, 5185. İstanbul: Koç Üniversitesi Yayınları.

Kimmel, K. L. (2001). "Interactive Journal Writing with Deaf and Hard-of-hearing College Students." Proceedings 2000: International Seminar on Teaching English to Deaf and Hard-of-hearing students at Secondary and Tertiary Levels of Education, Prague, Czech Republic, 2-4 November 2000. Ed. Daniela Janáková. Prague: Charles University, 104-120.

Ladd P. (2003). Understanding Deaf culture: In Search of Deafhood. Clevendon: Multilingual Matters Ltd.

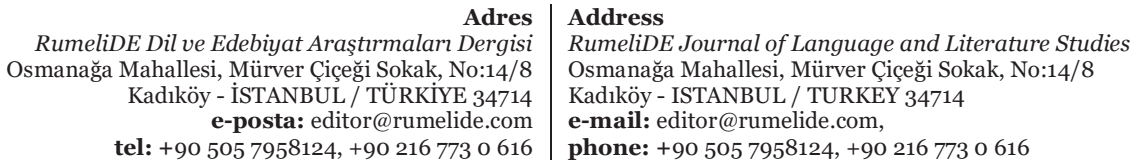

el: $+905057958124,+902167730616$

phone: +90 505 7958124, +90 2167730616 
1096 / RumeliDE Journal of Language and Literature Studies 2022.26 (February)

English language teaching model proposal for Deaf and Hard of Hearing students / S. Ay \& Ö. Şen Bartan (pp. 1082-1097)

Marschark, M. (2003). Cognitive functioning in deaf adults and children. In M. Marschark \& P.E. Spencer (Eds.), Oxford handbook of deaf studies, language and education. (pp. 464-477). New York: Oxford University Press.

Marschark, M. (2007). Raising and educating a deaf child: A comprehensive guide to the choices, controversies, and decisions faced by parents and educators. New York: Oxford University Press.

Mayberry, R.I. (2002). Cognitive development in deaf children: the interface of language and perception in neuropsychology. Handbook of neuropsychology (2nd ed.), Vol. 8, Part II (pp. 71107). Amsterdam: Elsevier.

Milli Eğitim Bakanlı̆̆ı. (2006). Özel eğitim hizmetleri yönetmeliği, 31.05.2006 tarih ve 26184 sayılı Resmi Gazete

Milli Eğitim Bakanlı̆̆ı. (2012). Özel eğitim hizmetleri yönetmeliği, 21.07.2012 tarih ve 26184 sayılı Resmi Gazete

Mole, J., McColl, H., \& Vale, M. (2006). Deaf and multilingual- a practical guide to teaching and supporting deaf learners in foreign language classes. Norbury, Shropshire: Direct Learn Services.

Morávková, V. (2011). Deaf students and their motivation to learn English, unpublished Bachelor Thesis, Masaryk University, Brno.

Moritz, N. (2016).Oral communication and intelligibility in Deaf speech. In Domagała-Zysk, Ewa and Kontra, Edit H (Eds.). English as foreign language for Deaf and Hard-of-Hearing persons: challenges and strategies (pp. 9-22). Cambridge: Cambridge Scholars Publishing

Nabiałek, A. (2016). Immersion in the English language for Deaf students. In E. Domagała-Zysk\& E. H. Kontra (Eds.), English as a foreign language for Deaf and Hard-of-hearing persons: Challenges and strategies (pp. 169-181). Newcastle upon Tyne: Cambridge Scholars.

Özel Eğitim Hizmetleri $\quad$ (2021, $\quad$ February 19). https://orgm.meb.gov.tr/meb_iys_dosyalar/2020_06/24163215_ozel_eYitim_yonetmeliYi_so n_hali.pdf

Piniel, K., Kontra, E. H.\&Csizér, K. (2016). Foreign language teachers at schools for Deaf and Hard-ofHearing students. In E. Domagala-Zysk\& E. H. Kontra (Eds.), English as a foreign language for Deaf and Hard of Hearing persons: Challenges and strategies (pp. 73-90). Cambridge, UK: Cambridge Scholars Publishing.

Podlewska, A. (2016). The Use of cued speech to support the development of verbal language skills in English language instruction for Deaf and Hard-Of-Hearing students." In English as a foreign language for Deaf and Hard of Hearing persons: Challenges and strategies, edited by E. Domagała-Zysk and E. H. Kontra, 23-40. London: Cambridge Scholars Publishing.

Pritchard, P. (2016). Experiences in teaching English to Deaf and Severely Hard-of-Hearing pupils in Norway. In English as a foreign language for Deaf and Hard of Hearing persons: Challenges and strategies, ed. By EvaDomagalaZysk, and Edit H. Kontra, 41-54. Cambridge Scholars Publishing.

Sedláčková, J. (2016). Challenges of reading comprehension development of deaf learners in the foreign language classroom: putting theory into practice. In E. Kontra\& E. Domagala-Zysk (Eds.), English as a foreign language for Deaf and Hard of Hearing persons - challenges and strategies. Newcastle-upon-Tyne, England: Cambridge Scholars Publishing Ltd.

Spencer, P.E., \& Marschark, M. (2010). Evidence-based practice in educating deaf and hard-of-hearing students. Oxford: Oxford University Press.

Szymanski, C., Lutz, L., Shahan, C., \& Gala, N. (2013, May). Critical needs of students who are Deaf and Hard of Hearing: A public input summary. Washington, DC: Gallaudet University, Laurent Clerc National Deaf Education Center.

Turan, A. Ç., Özel, C. ve Dayı, Ş. (2016). Engelli üniversite öğrencilerinin yabancı dil öğreniminde karşılaştı̆̆ı güçlükler hakkında rapor, https://www.eged.org/node/419

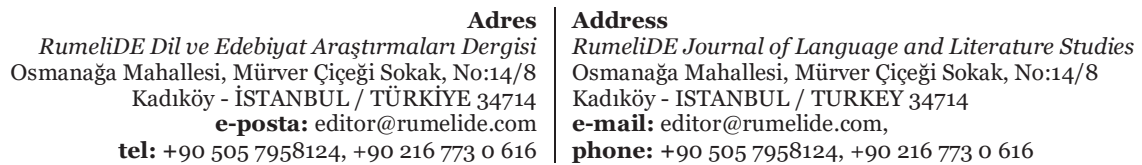


Turna,C. \& Güldenoğlu, İ B. (2019). Sesbilgisel çözümleme becerileri ile sözcük okuma hızı ve doğruluğu arasındaki ilişkinin gelişimsel bakış açısıyla incelenmesi, Eğitim ve Bilim 44 (198), 413-433.

Ünal Gezer, M. \& Dixon, L. Q. (2017). The role of phonology, morphology, and orthography in English word and pseudoword spelling performances of Turkish students across grades 6, 7, and 8 . International Online Journal of Education and Teaching (IOJET), 4 (2). 137-160. http://iojet.org/index.php/IOJET/article/view/177/157

Vanderplank, R. (2019) 'Gist watching can only take you so far': attitudes, strategies and changes in behaviour in watching films with captions, The Language Learning Journal, 47:4, 407-423, DOI: 10.1080/09571736.2019.1610033

Vygotsky, L. S. (1978). Mind in society: The development of higher psychological processes. Massachusetts: Harvard University Press.

Yang, (2020, February 10). https://www.children-learning-reading-review.com

Yükseköğretim Kurumu, (2021, September 20). https://engelsiz.yok.gov.tr/kararlar

Yükseköğretim Kurumu, (2021, September 20). https://engelsiz.yok.gov.tr/toplantilar

RumeliDE Dil ve Edebiyat Araştırmaları Dergisi Osmanağa Mahallesi, Mürver Çiçeği Sokak, No:14/8 Kadıköy - İSTANBUL / TÜRKIYE 34714 tel: $+905057958124,+902167730616$
RumeliDE Journal of Language and Literature Studies Osmanağa Mahallesi, Mürver Çiçeği Sokak, No:14/8 Kadıköy - ISTANBUL / TURKEY 34714 e-mail: editor@rumelide.com

phone: +90 $5057958124,+902167730616$ 